\title{
The Innovative Basis of the Growing Small and Medium-sized Businesses
}

\author{
Lesya Bozhko ${ }^{1 *}$ \\ ${ }^{1}$ Emperor Alexander I St. Petersburg State Transport University, St. Petersburg, Russia \\ *Email: lemib@rambler.ru
}

\begin{abstract}
The growth of the organisation, expressed in revenue and the number of staff increase, has a positive effect on the socioeconomic indicators of the country. The firm's innovative activity as a factor of intensive growth in current conditions is beyond doubt but requires additional analysis to ensure it, considering the problems of growing organisations. Identification of innovation-based success factors and solutions to the problems of growing companies are topical management issues. The study aims to determine the factors of innovative development that would be the basis for ensuring the growth of small and medium-sized organisations. By methods of selective observation and in-depth structured interviews with representatives of small and medium-sized businesses, approx. three hundred organisations from Russian regions were surveyed, growth factors based on innovations were determined. The study results allow us to see the problems of growth of firms and choose possible solutions in the field of innovation management when making investment decisions. This will smooth out the economic instability of the business during the period of growth and create sustainable competitive advantages.
\end{abstract}

Keywords: Organisational development, Organisational growth, Small business, Medium business, Innovative development, Organisational changes.

\section{INTRODUCTION}

Quite often, the attitude to the organisation is determined by its size. The firm's size speaks about the amount of its income and indicates its contribution to the state's economy. Small and medium-sized businesses can increase the scale of their activities, which means they can make a more significant contribution to the country's economic performance.

Ensuring business growth is relevant not only for the Russian economy but also for the economies of other developing countries. The growth of an organisation generally means an increase in its revenue (tax deductions), the number of personnel (employment of the population); i.e. it acts as a socio-economic benefit for the region and the country.

The growth and development of the company involve organisational changes. Special studies are devoted to organisational changes during technological start-ups [1], flexibility to ensure organisational development [2], the relationship between organisational flexibility and strategic human resource management [3], ensuring organisational efficiency as a prerequisite for the development of the organisation [4]. Of interest are studies about promoting the development of an organisation with a growth mindset [5], where the primary dominants of development are openness to opportunities, setting the task to become better, inspiration for the success of others. Several studies have studied the relationship between growth and organisational change $[6,7,8]$.

When studying the relationship between organisational innovations, growth, and the firm's size, it was found that organisational innovations positively impact the firm's growth if new business methods and new methods of workplace organisation are introduced [9]. For small and medium-sized organisations, it is recommended to use total innovation management as a tool to increase the efficiency of organisational development [10]. 
In the problem area under consideration, it is necessary to focus on organisational growth's problems and innovative factors. The innovative activity of an enterprise as a factor of intensive growth in current conditions is beyond doubt but requires special analysis to ensure it, considering the problems of growing organisations. Therefore, identifying innovation-based success factors for growing small and medium-sized businesses is an urgent issue to which this study is devoted

The study aims to determine the factors of innovative development that would be the basis for ensuring the growth of small and medium-sized organisations.

\section{MATERIALS AND METHODS}

To conduct the study, the analysis of the legislative base of the Russian Federation regulating the activities of small and medium-sized businesses was carried out. In particular, the regulatory criteria for classifying organisations as small, medium and large were studied.

When studying the impact of organisations of various sizes on the country's economy, statistical data analysis methods (grouping, dynamics series, indices), analytical comparisons were used. The information was obtained from open sources of Rosstat [11, 12].

In the course of the research, the literature was analysed on the issues of interest (organisational development, business development, innovation activity).

Obtaining results to identify the problems of growing organisations and their growth factors based on innovations was carried out using selective observation of small and medium-sized businesses and interviews with their representatives. 247 small and 46 mediumsized firms from 12 regions of the Russian Federation were surveyed. The survey was conducted for 8 years. To identify the success factors of growing organisations, the best practices of leading innovative organisations included in the national TechSuccess rating were studied [13].

\section{STUDY RESULT}

According to Russian legislation, organisations are divided into small, medium and large based on several criteria $[14,15]$.

An organisation is considered small if three conditions are met:

1) the average number for the previous year is up to 100 people;

2) income for the previous year - up to 800 million rubles;

3) in the structure of the authorised capital, the share of participation of state entities (the Russian Federation, subjects of the Russian Federation, municipalities), public and religious organisations, foundations in total should not exceed $25 \%$, the share of participation of legal entities, including foreign (not small and not mediumsized) should not exceed $49 \%$ in total. There are no restrictions on the share of participation of small and medium-sized enterprises in the authorised capital.

Small business entities include organisations and individuals engaged in entrepreneurial activities without forming a legal entity.

According to the currently accepted Russian standards, an organisation is considered average if:

1) the average number is from 101 to 250 people;

2) the income is over 800 million rubles, but not more than 2 billion rubles for the previous year;

3) restrictions on the authorised capital structure are the same for small organisations.

Changes in the legal framework in 2015-2016 doubled the income limits for small and medium-sized businesses and expanded its range. This affected the growth of the number of small organisations in 2016, the dynamic of which is presented in Table 1 .

The data for the compilation of table 1 were taken from official statistics reports (the most recent at the time of preparation of the article).

In 2016, the number of small firms increased by almost a quarter $(24.7 \%)$. At the same time, the number

Table 1. The number of small and medium-sized enterprises for 2010-2018, thousand

\begin{tabular}{|l|c|c|c|c|c|c|c|c|c|}
\hline \multirow{2}{*}{$\begin{array}{c}\text { Types of } \\
\text { enterprises }\end{array}$} & 2010 & 2011 & 2012 & 2013 & 2014 & 2015 & 2016 & 2017 & 2018 \\
\cline { 2 - 10 } & $1,644.3$ & $1,836.4$ & 2,003 & $2,063.1$ & $2,103.8$ & $2,222.4$ & $2,770.6$ & $2,754.6$ & $2,659.9$ \\
\hline Small & 25.2 & 15.9 & 13.8 & 13.7 & 13.7 & 19.3 & 13.3 & 13.3 & 13.7 \\
\hline Medium &
\end{tabular}


of medium-sized organisations decreased by nearly a third $(31.1 \%)$. Subsequently, there was a tendency to reduce the number of small enterprises with a slight increase in the number of medium-sized ones in 2018. The maximum was reached in 2015: there was an increase of 5.6 thousand compared to the previous year. However, in 2016, an increase in the number of small enterprises by 548.2 thousand was accompanied by a decrease in the number of medium-sized enterprises by 6 thousand.

Large enterprises have a decisive influence on the Russian economy. The study of the contribution of small and medium-sized enterprises to the main economic indicators recorded its small relative value $[16$, p. 71].

It was found that common problems of growing small and medium-sized businesses are:

1. The need to attract finance. The organisation attracts external financing; loans are paid for at the expense of current profits, while new projects do not yet provide cash receipts. Sometimes the primary resources to support the development of innovative projects are venture capital companies that invest a lot of money both at the initial stages and at the stages of development and expansion of projects [17].

2. The need for qualified personnel. The innovative basis of growth requires the labour of qualified specialists. For developing countries' digital economies, the need to strengthen labour potential is an urgent task [18].

3. The need for constant organisational changes. The period of growth means a series of organisational changes, and they require the mobilisation of resources, special attention, are usually experienced painfully and cause resistance. Responding to external factors becomes possible by obtaining up-to-date market information [19].

Other problems besides those listed here are not excluded. Knowledge of the development problems of growing organisations allows you to choose ways to overcome economic vulnerability and focus on growth factors. An example of the successful growth of organisations is gazelle firms, which represent the pride

Table 2. Types of economic activity with the highest values of the level of innovation activity

\begin{tabular}{|c|c|c|}
\hline Types of economic activity & 2018 & 2019 \\
\hline Total & 12.8 & 9.1 \\
\hline \multicolumn{3}{|l|}{ including, by type of economic activity: } \\
\hline industrial production & 15.6 & 15.1 \\
\hline $\begin{array}{l}\text { including: } \\
\text { manufacturing industries }\end{array}$ & 23.2 & 20.5 \\
\hline \multicolumn{3}{|l|}{ including: } \\
\hline manufacture of computers, electronic and optical products & 53.6 & 49.8 \\
\hline production of electrical equipment & 43.9 & 41.1 \\
\hline production of machinery and equipment not included in other groups & 45.3 & 40.9 \\
\hline manufacture of motor vehicles, trailers and semi-trailers & 40.5 & 36.6 \\
\hline production of medicines and materials used for medical purposes & 42.7 & 35.6 \\
\hline metallurgical production & 31.3 & 29.0 \\
\hline production of coke and petroleum products & 31.0 & 27.5 \\
\hline production of fabricated metal products, except machinery and equipment & 30.6 & 26.6 \\
\hline production of chemicals and chemical products & 29.8 & 26.0 \\
\hline manufacture of other vehicles and equipment & 24.0 & 22.6 \\
\hline research and development & 61.4 & 51.3 \\
\hline
\end{tabular}


of the Russian economy. Basically, such companies are medium-sized or fast-growing small ones.

If we turn to the level of innovation activity of organisations in the Russian Federation, its most significant values fall on industrial production, manufacturing and scientific research (Table 2). Rosstat calculates this indicator under the international recommendations on the statistical measurement of innovation - the Oslo Manual (Oslo Manual: Guidelines for Collecting, Reporting and Using Data on Innovation).

Table 2 is compiled according to Rosstat data [12] (the most recent at the time of submission of the article). The table includes activities in which the level of innovation activity is above $15 \%$ and in the context of activities - above $20 \%$.

In 2019, compared to the previous year, the overall level of innovation activity decreased, and there was also a decrease in the top 3 types of economic activity. In the manufacturing industries, the leading areas are the production of computers, electronic and optical products; the production of electrical equipment; the production of machinery and equipment not included in other groupings. These are not the most popular areas for small businesses, but there are growing organisations.

When analysing data on innovation activities of small and medium-sized enterprises for 2017 (the most recent data at the time of submission of the article) [11], it was found that the share of enterprises implementing technological innovations in the total number of surveyed enterprises is $5.8 \%$ in manufacturing, including the production of computers, electronic and optical products $(19.2 \%)$, the production of medicines and materials used for medical purposes $(16.8 \%)$, the production of electrical equipment $(11.9 \%)$, the production of other finished products $(10.5 \%)$

In Russia, since 2016, the national rating of fastgrowing companies - TechSuccess - has been compiled [13], which is the basic one for selecting companies participating in the project of the Ministry of Economic Development of the Russian Federation "Support for private high-tech leading Companies" ("National Champions"). The rating is compiled for small, medium and large companies; the top 15 includes five organisations of each size.

The analysis of the best practices of innovative activities of successful fast-growing companies included in the TechSuccess rating and other companies showed that despite the uniqueness of the business, fast-growing companies are characterised by common success factors associated with innovation.

The innovative basis of fast-growing firms consists of the following factors:
1. Work in the advanced technology markets, which have a large potential market capacity and open up further development prospects.

2. Highly qualified employees who create innovative ideas and implement them into hard-to-copy products.

3. Development of products that require engineering and technical support for the client. The transaction with the client is not limited to a one-time purchase and sale act but involves cooperation for a long time.

4. Establishing partnerships with large organisations that ensure the growing demand for high-tech products. The needs of customer enterprises in high-tech solutions stimulate innovative developments of companies, the expansion of the scale of customer activities contributes to the growth of sales of the manufacturing company.

5. Working in differentiated and targeted markets where competition is relatively low, there is an opportunity for international expansion for sales.

6. The experience of conducting innovation activities for several years, which, in turn, allowed us to accumulate experience in risk management of innovative projects.

\section{DISCUSSION}

It is logical to assume that growing companies are mostly small businesses that start their activities. Already in the second year, they demonstrate an increase in revenue due to working part-time during creation, and the effect of a low base in the first year of work is also affected compared with subsequent results. As our observations show, small businesses (especially family businesses) are often not inclined to continue growing, having achieved acceptable levels of revenue and profitability.

Ensuring the growth of the company requires organisational innovations, which requires special attention from the management team. You can name many factors of business growth and development. In this study, in the light of increased investment activity and the prospects for innovative development of developing countries, the success factors of growing organisations based on innovation were identified.

\section{CONCLUSIONS}

The results of the study - certain problems of growing organisations and innovation-based factors of successful growth - allow us to consider the difficulties that arise during the growth of the organisation, to foresee them when planning investments, innovation activities, to find possible solutions before starting the implementation of the growth strategy. Using the study results allow for smoothing out economic instability and reducing risks 
during the transition period, increasing the chances of success of organisations.

The key success factors of growing organisations are based on innovation and involve not only the introduction of technically advanced solutions into production but also the formation of highly qualified, innovation-ready personnel, the creation of an innovative culture in the organisation, innovative marketing activities.

The creation of a favourable innovation and investment climate in the country with the favourable influence of macroeconomic factors will contribute to the innovative activity of organisations regardless of size and the successful elimination of growth problems at the micro-level.

\section{REFERENCES}

[1] M.Z. Okanovic, M.V. Jevtic, T.D. Stefanovic, Organisational changes in the development process of technology start-ups // Lecture Notes in Networks and Systems 153 (2021) 203-219. DOI: https://doi.org/10.1007/978-3-030-58362-0_13

[2] H.-J. Gergs, Agility and organisational Development - Pretty Best Friends? How organisational development can support the digital transformation of companies and how it has to change itself // Gruppe. Interaktion. Organisation. Zeitschrift fur Angewandte Organisations psychologie 50(2) (2019) 101-110. DOI: https://doi.org/10.1007/s11612-019-00463-3

[3] N. Saha, T. Saha, P. Saha, Organisational agility and strategic HRM: A twin perspective strategy of organisational capacity and knowledge development // Proceedings of the 33rd International Business Information Management Association Conference, IBIMA 2019: Education Excellence and Innovation Management through Vision 2020, 2019, pp. 1132-1136.

[4] A. Baughen, C. Oswick, R. Oswick, Rethinking' Organisational Effectiveness' as a Core Premise of organisation Development: Beyond Narrow organisational Interests and Towards Wider Soulful Interventions // Journal of Change Management 20(4) (2020) 333-341. DOI: https://doi.org/10.1080/14697017.2020.1746684

[5] J.O.E. Austinaustin, A. Collins, Nurturing organisational development using growth mindset // Regulatory Rapporteur 17(3) (2020) 7-9.

[6] J. Bateh, S. Sofianopoulou, Organisational growth through operational change // International Journal of Business Performance Management 20(3) (2019) 278-296.

DOI:
[7] M.A. Norcross, M.R. Manning, Humility as an enabler of organisational growth and change // Research in Organisational Change and Development 27 (2019) 59-82. DOI: https://doi.org/10.1108/S0897301620190000027005

[8] Pons-Pons J., Vilar-Rodríguez M. The genesis, growth and organisational changes of private health insurance companies in Spain (1915-2015) // Business History. 3 April 2019. Volume 61, Issue 3. Pp. 558-579. DOI: https://doi.org/10.1080/00076791.2017.1374371

[9] A. Nugraha Irwansyah, Purwadi, How digital knowledge sharing affects innovation work behaviour and organisational innovation capability in terms of sustainable development goals // IOP Conference Series: Earth and Environmental Science 716(1) (2021) 012058. DOI: https://doi.org/10.1088/1755-1315/716/1/012058

[10] J.F. Al-Hyari, M.M. Al-Nsour, The impact of total innovation management on organisational development in Jordanian small and medium-sized industrial companies // Jordan Journal of Business Administration 16(1) (2020) 195-21.

[11] Small and medium entrepreneurship in Russia 2008, 2009, 2010, 2013, 2014, 2015, 2017, 2019 [Maloe i srednee predprinimatel'stvo v Rossii 2008, 2009, 2010, 2013, 2014, 2015, 2017, 2019 g.] / Federal state statistics service [Federal'naya sluzhba gosudarstvennoj statistiki] [Electronic resource]. Access mode: https://www.gks.ru/folder/210/document/13223 (accessed: 22.01.2020).

[12] Science, innovation and advanced production technologies: The level of innovative activity of organisations // Technological development of economic sectors [Nauka, innovacii i peredovye proizvodstvennye tekhnologii: Uroven' innovacionnoj aktivnosti organizacij // Tekhnologicheskoe razvitie otraslej ekonomiki] / Federal State Statistics Service [Federal'naya sluzhba gosudarstvennoj statistiki] [Electronic resource]. Access mode: https://rosstat.gov.ru/folder/11189 (accessed: 05/10/2021).

[13] Technical success. National rating of Russian fastgrowing technology companies [TekhUspekh. Nacional'nyj rejting rossijskih bystrorastushchih tekhnologicheskih kompanij] [Electronic resource]. Access mode: http://ratingtechup.ru (accessed: 05/10/2021). https://doi.org/10.1504/IJBPM.2019.102026 
[14] Federal Law of the Russian Federation No. 209-FZ dated July 24, 2007 "On the Development of Small and Medium-sized Businesses in the Russian Federation" [FZ RF ot 24 iyulya 2007 g. № 209-FZ $« O$ razvitii malogo i srednego predprinimatel'stva $\mathrm{v}$ Rossijskoj Federacii»].

[15] Decree of the Government of the Russian Federation No. 265 dated April 04, 2016 "On the limits of income from entrepreneurial activity" [Postanovlenie Pravitel'stva RF ot 04 aprelya 2016 № 265 «O predel'nyh znacheniyah dohoda ot predprinimatel'skoj deyatel'nosti»].

[16] L.M. Bozhko, Assessment of the dynamics of the development of small and medium-sized organisations to justify their need for organisational changes [Ocenka dinamiki razvitiya malyh i srednih organizacij dlya obosnovaniya ih potrebnosti $\mathrm{v}$ organizacionnyh izmeneniyah] // Bulletin of Tver State University: Series "Economics and Management" [Vestnik Tverskogo gosudarstvennogo universiteta: Seriya «Ekonomika i upravlenie»] 4 (2019) 67-73.

[17] I. Reshetnikova, O. Yanina, L. Semenova, L. Bozhko, O. Veselitsky Problem of Assessing the Investment Attractiveness of Risk Projects for Developing Artificial Intelligence // International journal of recent technology and engineering 8(2S10) (2019) 238-243. DOI: https://doi.org/10.35940/ijrte.B1041.0982S1019

[18] B. Miethlich, S. Kvitka, M. Ermakova, L. Bozhko, O. Dvoryankin, S. Shemshurina, I. Kalyakina, Correlation of Educational Level, Labor Potential and Digital Economy Development in Slovakian, Ukrainian and Russian Experience // TEM Journal, Vol. 9, Issue 4, pp. 1597-1605. DOI: https://doi.org/10.18421/TEM94-35

[19] N.T. Israfilov, E.A. Shnyreva, E.E. Panfilova, L.M. Bozhko, V.A. Konstantinov, Market information and entrepreneurship education: A case of transition economies // Journal of Entrepreneurship Education 22(3) (2019) 1-10. 